\title{
A 15-Year Analysis of Surface Ozone Pollution in the Context of Hot Spells Episodes over Poland
}

\author{
Joanna STRUZEWSKA and Maciej JEFIMOW \\ Faculty of Building Services, Hydro and Environmental Engineering, \\ Warsaw University of Technology, Warsaw, Poland \\ e-mail: joanna.struzewska@is.pw.edu.pl
}

\begin{abstract}
Analysis of summertime temperature characteristics and ozone exposure indexes were carried out for eight locations in Poland for a 15year period (1997-2011). The number of days with the maximum temperature exceeding $25^{\circ} \mathrm{C}$ and $30^{\circ} \mathrm{C}$ was calculated for each year. The analysis covered the 8-hour running average and daily maximum of near surface ozone concentrations. Also, the accumulated exposure when ozone concentrations were above $120 \mu \mathrm{g} / \mathrm{m}^{3}$ (AOT60) was calculated as a diagnostic indicator of adverse health effects for each year. Although high ozone concentrations are associated with hot temperatures, the exposure to values higher than $120 \mu \mathrm{g} / \mathrm{m}^{3}$ is correlated with the length of the hot weather period rather than with the occurrence of days with extremely high temperatures. In most cases the elevated ozone concentrations occurred during days when the maximum temperature was higher than $24^{\circ} \mathrm{C}$. Episodes of very high ozone concentrations, exceeding $180 \mu \mathrm{g} / \mathrm{m}^{3}$, were not associated with heat wave periods at analysed locations.
\end{abstract}

Key words: hot spells, heat waves, ozone pollution, ozone exposure, ozone episodes. 


\section{INTRODUCTION}

Photochemical ozone formation is strongly influenced by meteorology. Air temperature is often treated as a surrogate for meteorological factors such as enhanced solar irradiance, reduced cloudiness and calms (Jacob et al. 1993, Ryan et al. 1998, Sillman 1999, Camalier et al. 2007). Based on the neural network method, Stathopoulou et al. (2008) showed that temperature is the main parameter affecting ozone concentration levels.

A number of studies established that for the temperature range from $17^{\circ}$ to $32^{\circ} \mathrm{C}$ the increase of ozone concentration is approximately linear (Bloomer et al. 2009, Camalier et al. 2007, Mahmud et al. 2008, Sillman and Samson 1995). According to Steiner et al. (2010), ground level ozone concentrations show a direct linear relationship with surface air temperature. However, observations in California provide compelling evidence that ozone maximum concentrations may plateau or decrease under extremely high temperatures $>39^{\circ} \mathrm{C}$ due to a strong e-folding decrease of PAN (Peroxyacetyl nitrate) and a reduction of isoprene emissions. Almost linear ozone increase with temperature was found by Im et al. (2011), who studied the impact of temperature changes on ozone in the Eastern Mediterranean.

The impact of temperature on atmospheric ozone occurs both directly through the temperature dependence of ozone forming reactions (Sillman and Samson, 1995) and indirectly through the temperature dependence of dry deposition through stomatal uptake (e.g., Wesley 1989, Solberg et al. 2008). Biogenic emissions of ozone precursors also increase with temperature (e.g., Guenther et al. 1993), which favours ozone formation.

Based on model simulation for the summer 2007 period over the Mediterranean Hodnebrog et al. (2012) showed that the direct impact of high temperatures on ozone chemistry was low (less than $1 \mathrm{ppb}_{\mathrm{v}}$ on average over the region) because high temperatures lead to both faster ozone production and ozone destruction.

Vieno et al. (2010) and Solberg et al. (2008) highlighted the role of surface dry deposition during the European 2003 summer heat wave, indicating that reduced uptake from vegetation due to drought contributed significantly to high ozone levels. Furthermore, simulations by Solberg et al. (2008) showed that biogenic isoprene emissions contributed up to $20 \%$ to the peak ozone values and a $10^{\circ} \mathrm{C}$ increase led to a $5 \%$ increase in peak ozone values.

Observational studies indicate strong correlation between surface temperature and ozone concentrations on multiple time scales (Bloomer et al. 2009, Camalier et al. 2007, Cardelino and Chameides 1990, Clark and Karl 1982, Korsog and Wolff 1991) including monthly average ozone and monthly average temperatures in the warm season (Rasmussen et al. 2012). 
Substantial increases in surface ozone are documented in Western Europe during the summer period of 2003 (e.g., Vautard et al. 2005, Fiala et al. 2003, Solberg et al. 2008). Photochemical pollution during the exceptionally warm summer period in Zagreb in 2006 was shown by Pehnec et al. (2009). Also, research undertaken in the AQMEII (Air Quality Modelling Evaluation International Initiative) project focused on the photochemical pollution during summers of 2006 (i.e., Solazzo et al. 2012) and 2010 (i.e., Im et al. 2015).

Assessment of the exposure to ozone concentrations during summer periods in Europe is reported by the European Environmental Agency (EEA). Measurement-based analysis of the exposure to high ozone concentrations is presented together with the average maximum daily temperature recorded in selected European cities.

Although the relation between temperature and ozone pollution was confirmed in numerous studies, only limited publications focus on photochemical pollution during hot spells and heat waves.

Ozone pollution during heat waves was analysed over Western Europe for August 2003 (Pellegrini et al. 2007, Tressol et al. 2008) and July 2006 over Central Europe (Struzewska and Kaminski 2008). The assessment of ozone pollution in Athens during heat waves that occurred in the last decade was presented by Papanastasiou et al. (2014). A relatively high positive correlation between ozone and air temperature in terms of the probability of the number of days with ozone exceedances in respect to a given maximum daily temperature was found in North Rhine-Westphalia, Germany, for the period of 1983-2007 (Melkonyan and Wagner 2013).

The aim of the presented study is to analyse a long-term variability of temperature characteristics and surface ozone concentrations based on measurements from eight locations in Poland. An attempt was made to establish the relationship between the hot weather periods and ozone pollution in Poland. Also, the heat wave periods were identified and analysed in the context of ozone exposure.

\section{OBSERVATIONS AND METHODS}

The presented analyses were undertaken for the 15-year period 1997-2011. Ozone measurements were obtained from the EEA AirBase data archive (http://acm.eionet.europa.eu/databases/airbase). Eight air quality rural background stations with relatively complete and homogenous ozone measurement time series for the analysed period were selected (Fig. 1). Four stations along the south-western borders of Poland were selected as most severe ozone episodes in Poland are associated with situations when local ozone 


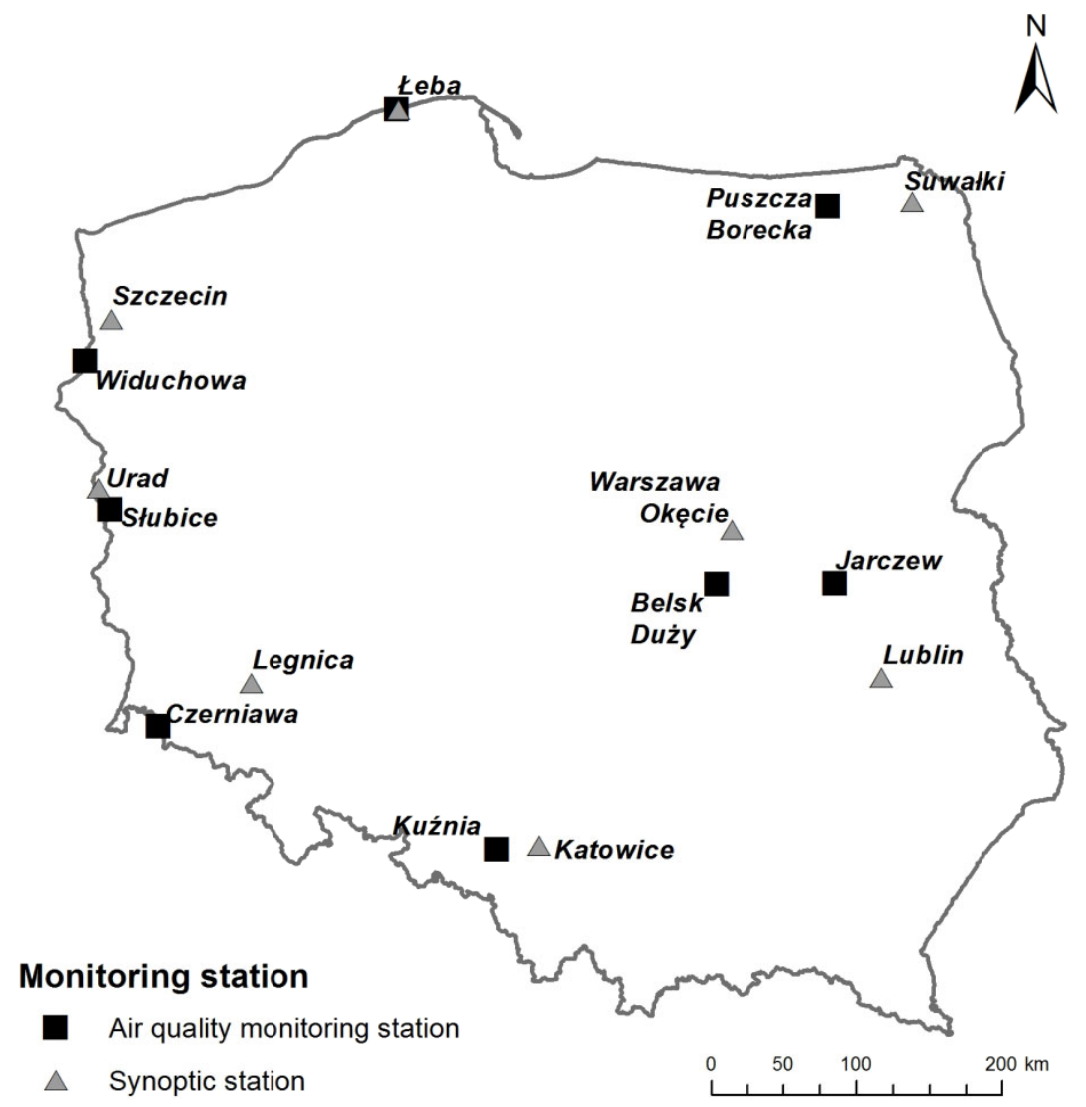

Fig. 1. Location of stations (squares: air quality monitoring stations, triangles: synoptic stations).

production was combined with the inflow of ozone-rich air masses from Western Europe (Struzewska et al. 2006).

Due to limited availability of meteorological observations, that would satisfy the WMO requirements, at air quality monitoring stations, the temperature measurements were taken from synoptic stations, which are representative over a $50 \mathrm{~km}$ radius. Selection of synoptic stations was based on the shortest distance from the air quality monitoring stations. Daily maximum temperatures $\left(T_{\max }\right)$ were taken from NOAA/GSOD dataset (Global Summary of the Day) (https://data.noaa.gov/dataset/global-surfacesummary-of-the-day-gsod). Location information of the selected station pairs is summarized in Table 1. 
Table 1

List of station pairs used in the study

\begin{tabular}{|c|c|c|c|c|c|}
\hline No & Station & $\begin{array}{c}\text { Latitude } \\
\text { (North) }\end{array}$ & $\begin{array}{c}\text { Longitude } \\
\text { (East) }\end{array}$ & $\begin{array}{c}\text { Elev. } \\
{[\mathrm{m} \text { a.s.1.] }}\end{array}$ & Station code \\
\hline \multirow[b]{2}{*}{1.} & Belsk Duży & 51.833 & 20.792 & 176 & PL0014A \\
\hline & $\begin{array}{c}\text { Warszawa } \\
\text { Okęcie }\end{array}$ & 52.163 & 20.961 & 107 & 12375 \\
\hline \multirow{2}{*}{2.} & Czerniawa & 50.910 & 15.314 & 645 & PL0028A \\
\hline & Legnica & 51.200 & 16.200 & 124 & 12415 \\
\hline \multirow{2}{*}{3.} & Jarczew & 51.810 & 21.973 & 180 & PL0002R \\
\hline & Lublin & 51.217 & 22.393 & 240 & 12495 \\
\hline \multirow{2}{*}{4.} & Kuźnia & 50.210 & 18.617 & 237 & PL0024A \\
\hline & Katowice & 50.233 & 19.033 & 284 & 12560 \\
\hline \multirow{2}{*}{5.} & Leba & 54.760 & 17.514 & 4 & PL0004R \\
\hline & Łeba & 54.754 & 17.535 & 2 & 12120 \\
\hline \multirow[t]{2}{*}{6.} & $\begin{array}{l}\text { Puszcza } \\
\text { Borecka }\end{array}$ & 54.133 & 22.067 & 157 & PL0005R \\
\hline & Suwałki & 54.131 & 22.948 & 186 & 12195 \\
\hline \multirow{2}{*}{7.} & Urad & 52.227 & 14.724 & 30 & PL0030A \\
\hline & Stubice & 52.350 & 14.600 & 24 & 12310 \\
\hline \multirow{2}{*}{8.} & Widuchowa & 53.127 & 14.385 & 2 & PL0182A \\
\hline & Szczecin & 53.395 & 14.623 & 3 & 12205 \\
\hline
\end{tabular}

\section{RESULTS}

The daily maximum temperature was used to analyse the climatology of hot weather periods in Poland. For all analysed stations the following indexes were calculated:

number of days with $T_{\max }>25^{\circ} \mathrm{C}$ (hot days),

a average temperature during hot days,

口 number of days with $T_{\max }>30^{\circ} \mathrm{C}$ (very hot days),

$\square$ average temperature during very hot days,

number of heat waves, defined as periods of at least three consecutive days with $T_{\max }>30^{\circ} \mathrm{C}$.

The number of very hot days is a subset of the number of hot days. A heat wave, defined as a prolonged period of excessively hot weather, is not precise and may vary depending on the region and climate type. In this work, we adopted a methodology based on temperature thresholds. Following Meehl and Tebaldi (2004), Della-Marta et al. (2007), Kyselý (2010), and Twardosz and Batko (2012), heat waves over Central Europe are defined as 
a period of at least three consecutive days with a maximum temperature exceeding $30^{\circ} \mathrm{C}$.

Recent studies of thermal extremes during summer months in Poland in 1951-2010 showed increasing frequency of the number of extremely warm day (Graczyk and Kundzewicz 2015, Twardosz and Kossowska-Cezak, 2015). In Central Europe, hot spells can be associated with an inflow of two different types of air masses (subtropical from the south or transformed polar from westerly directions), which indicate the differences in contribution of transboundary transport of ozone and its precursors. To assess the impact of high temperature on ozone pollution, the following ozone concentration indexes were calculated:

口 number of days with 8-hour moving average exceeding $120 \mu \mathrm{g} / \mathrm{m}^{3}$,

口 accumulated exposure to concentrations higher than $120 \mu \mathrm{g} / \mathrm{m}^{3}$ (in respect to 8-hour moving average),

$\checkmark$ daily maximum above the information threshold of $180 \mu \mathrm{g} / \mathrm{m}^{3}$.

The occurrence of hot and very hot days, as well as the number of days with elevated ozone concentrations, were assessed for each year and each station to assess trends and interannual variability over the 15 -year period and to analyse spatial differences in high temperature characteristics.

\subsection{Temperature}

In terms of hot days, the highest number occurred in 2002, 2003, 2006 and 2007. Most often hot days were recorded at stations located along the southwestern border of Poland: Legnica (49 days on average, with the maximum of 65 days in 2002), Katowice (45 days on average, with the maximum of 63 days in 2002) and Stubice (43 days on average, with the maximum of 69 days in 2003). A high number of hot days was also observed at WarsawOkęcie station located in the central part of Poland (45 days on average, with the maximum of 71 days in 2002).

The smallest number of hot days occurred in 1997 (27 days on average), 1998 (23 days on average) and 2004 (27 days on average). For Łeba station, located at the seaside, the number of hot days was smallest (14 days on average) as compared to other stations. However, the number of hot days was significantly higher (28 days) in 2002.

The average number of hot days, as well as the range of variability among stations observed for a particular year, is presented in Fig. 2. The bottom and top of the box represent the first and third quartiles, the band inside the box is the median. Ends of the whiskers represent the lowest datum within 1.5 IQR (interquartile range) of the lower quartile and the highest datum (data outside the 1.5 IQR). 


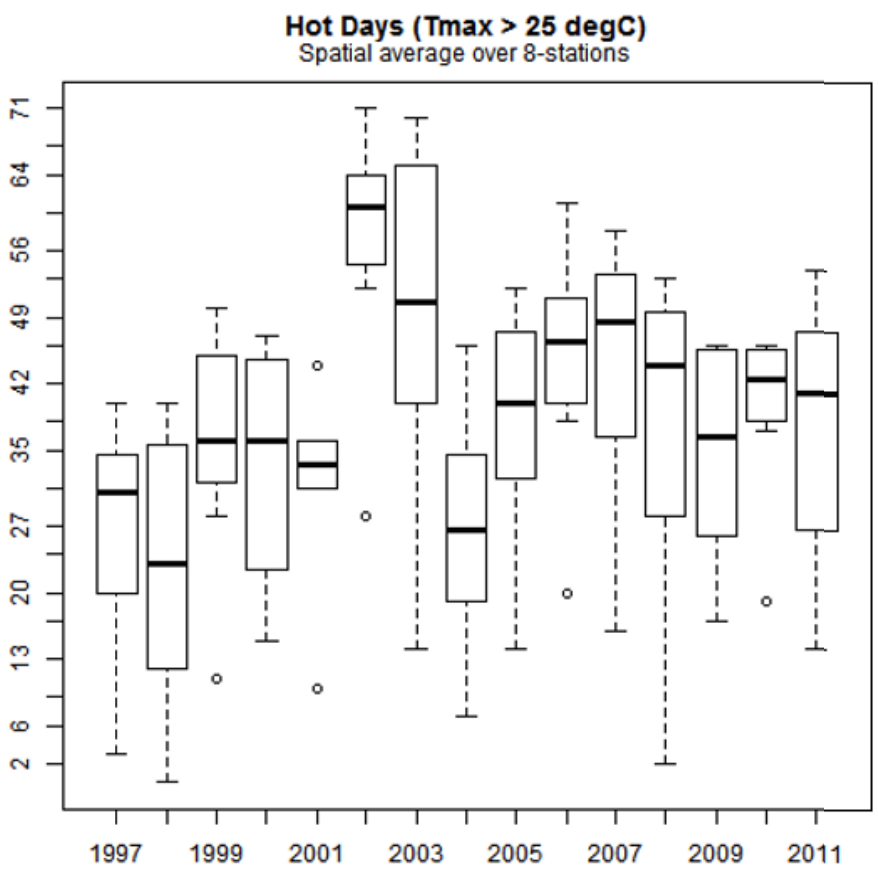

Fig. 2. Number of hot days in 1997-2011 (based on eight synoptic stations).

The average daily temperature during hot days of the analysed period was calculated for each station for each year. The highest temperature during hot days on average occurred in $2010\left(28.91^{\circ} \mathrm{C}\right)$ and $2006\left(28.71^{\circ} \mathrm{C}\right)$. In other years, the temperature during the hot day periods was $1^{\circ} \mathrm{C}$ lower $\left(27.5 \pm 0.4^{\circ} \mathrm{C}\right)$. Two stations located in the western part of Poland - Stubice and Legnica - were characterized with highest average temperature during hot days $\left(28.08^{\circ} \mathrm{C}\right.$ and $28.00^{\circ} \mathrm{C}$, respectively). Although the number of hot days in Łeba was lower than for other stations, the average temperature during hot day periods is comparable, and in 2010 was higher than for other stations $\left(29.13^{\circ} \mathrm{C}\right)$.

Figure 3 shows the maximum temperature averaged over stations during hot day periods for each year over the analyzed period. The variability represented as the highest and the lowest maximum temperature observed in a particular year at stations selected for the analysis is in the range of 26$29^{\circ} \mathrm{C}$. From 1997 to 2005 the maximum temperature during hot days averaged over all stations does not show any trend. The variability observed dur ing the rest of the period is due to exceptionally hot summers in 2006 and 2010. However, in 2006, the temperature difference between the highest and the lowest maximum temperature recorded during hot days was approx- 


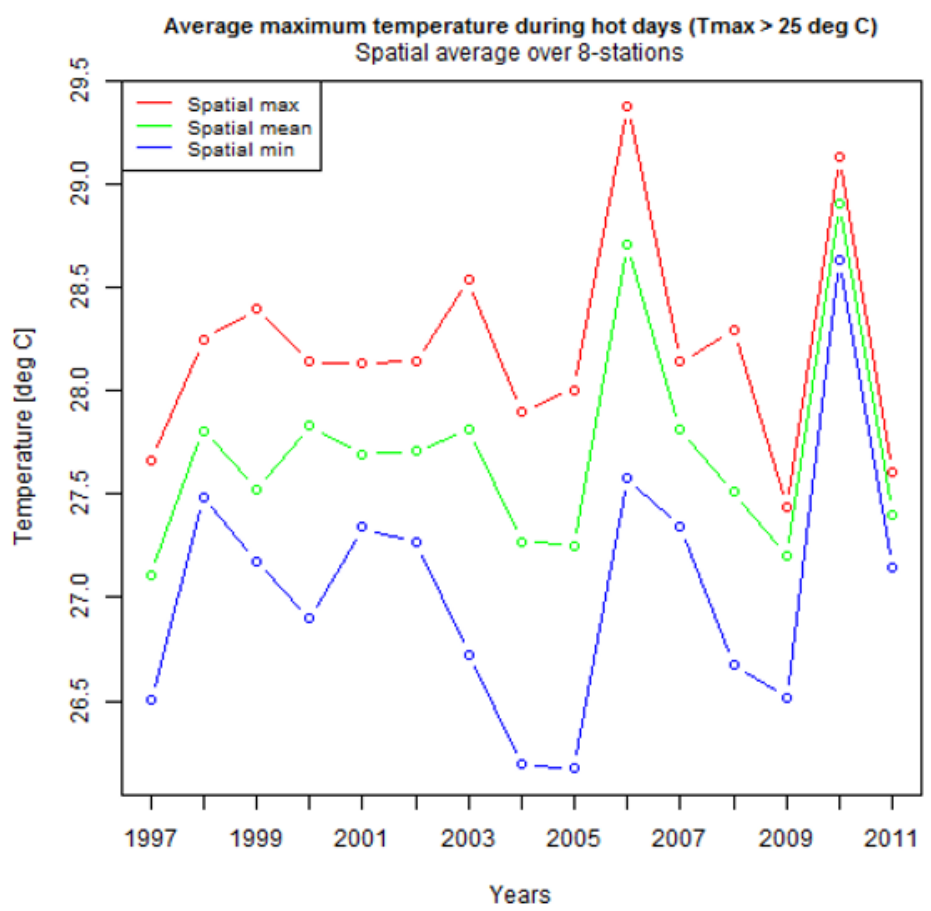

Fig. 3. Average maximum temperature during hot days (green line - spatial average over eight synoptic stations; blue line - minimum, red line - maximum).

imately $2^{\circ} \mathrm{C}$ while in 2010 the differences between stations were substantially smaller (less than $1^{\circ} \mathrm{C}$ ) and on average the maximum temperature during hot days was the highest in the analysed 15-year period.

During the analysed 15-year period the highest number of very hot days $\left(T_{\max }>30^{\circ} \mathrm{C}\right)$ occurred in 2006 (14 days on average) and 2010 (13 days on average), especially at Słubice (22 and 15 days, respectively), Warsaw Okęcie (22 and 17 days) and Legnica (21 and 14 days). A relatively large number of very hot days was observed in 2003 ( 8 days on average) and 2002 (7 days on average). However, in 2002, the number of very hot days was similar at most of the stations - in the range of 8 to 10. In 2003, the number of very hot days was much higher in Stubice (14 days) and Legnica (17 days), located at the western border of Poland, which was probably connected with the inflow of hot air masses from over Western Europe, where summer season 2003 was exceptionally high. Similar effect was observed in 2008 when the number of hot days in Stubice and Legnica was significantly higher than observed at other stations (12 and 13 days, respectively). 


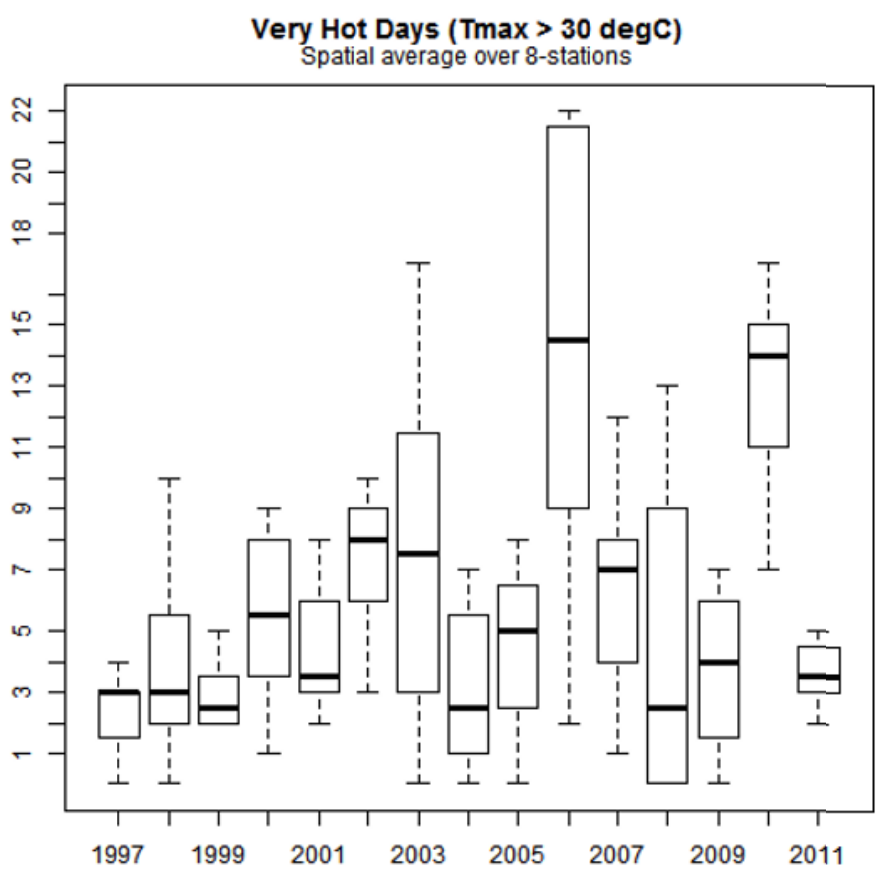

Fig. 4. Number of very hot days in 1997-2011 (based on eight synoptic stations).

The smallest number of very hot days occurred in 1997 ( 2 days on average). The exposure to very high temperature was smallest at Łeba station, which is located at the seaside ( 2 days on average). During the analysed period, very hot days were not observed at this station in four years (2003, 2004, 2005 and 2008). Suwałki station, located in the north-eastern part of Poland, is also characterized by a small number of very hot days (3 days on average). Very hot days were not observed at this location in 2004, 2008 and 2009. However, in contrast to Łeba, in 2006 and 2010 the number of very hot days in Suwałki was comparable to other stations ( 8 days and 14 days, respectively). The number of very hot days seems to have an increasing trend with an increasing variability over the analysed 15 -year period (Fig. 4).

The maximum temperature during the very hot days was calculated for each analysed station from 1997 to 2011. For all stations, the average temperature during very hot days is in the range of $31.5 \pm 0.3^{\circ} \mathrm{C}$. In Słubice, Katowice, Łeba and Suwałki very hot days were not observed in some years. However, this did not impact the intensity of the hot spells, if observed. The highest maximum temperature during very hot days $-33.13^{\circ} \mathrm{C}-$ was observed in 1998 at Warsaw-Okecie. 


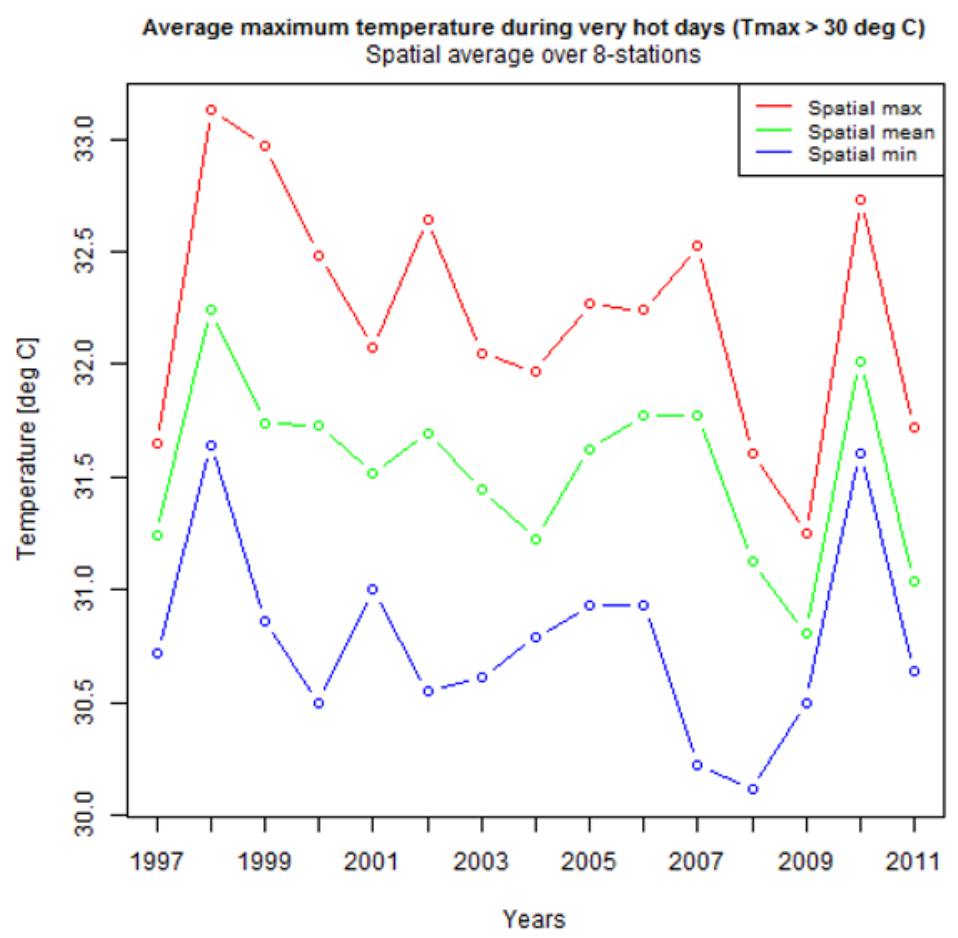

Fig. 5. Average maximum temperature during very hot days in 1997-2011 (green line - spatial average over eight synoptic stations; blue line - minimum, red line maximum).

Figure 5 shows the maximum temperature during very hot days averaged ovr all stations. The highest mean temperature was calculated for 1998 and 2010. A trend was not detected for the maximum temperature during very hot days for the analysed period.

Based on the maximum temperature record, the heat wave periods, defined as at least three consecutive days with the maximum temperature exceeding $30^{\circ} \mathrm{C}$, were identified (Table 2). Over the analysed period and region, such spells were usually short, 3-4 days. In most cases there were 1-2 heat waves per year, most often in July. An exception was 2006 with 3 prolonged periods of very hot weather.

In 2009 and 2011 heat waves were not detected at any of the analysed stations. At Łeba station, heat waves were not detected during the analysed period at all. A relatively small number of heat waves were found at Suwałki station (3 hot spells during 15 years). The highest number of heat waves was 
Table 2

Heat wave periods in 1997-2011

(more than three consecutive days with $T_{\max }>30^{\circ} \mathrm{C}$ )

\begin{tabular}{|c|c|c|c|c|c|c|c|}
\hline & Słubice & Katowice & Legnica & Lublin & Suwałki & Szczecin & W-wa O. \\
\hline 1997 & & $\begin{array}{c}28-30 \\
\text { Jun }\end{array}$ & & & & & $\begin{array}{c}28-30 \\
\text { Jun }\end{array}$ \\
\hline 1998 & & $\begin{array}{c}20-23 \\
\text { Jun }\end{array}$ & 20-23 Jun & & & & \\
\hline 1999 & & 4-6 Jul & & & & & 4-6 Jul \\
\hline 2000 & 19-22 Jun & $\begin{array}{c}19-21 \\
\text { Aug }\end{array}$ & 20-22 Jun & $\begin{array}{c}19-21 \\
\text { Aug }\end{array}$ & & $\begin{array}{c}20-22 \\
\text { Jun }\end{array}$ & $\begin{array}{c}20-22 \\
\text { Jun }\end{array}$ \\
\hline 2001 & & & & $15-17 \mathrm{Jul}$ & & & $\begin{array}{c}\text { 14-16 Jul } \\
19-21 \\
\text { Aug }\end{array}$ \\
\hline 2002 & $\begin{array}{l}\text { 9-11 Jul } \\
28 \text { Jul- } \\
\text { 2Aug }\end{array}$ & & $\begin{array}{l}\text { 9-11 Jul } \\
28 \text { Jul-2 } \\
\text { Aug }\end{array}$ & & $\begin{array}{c}29 \mathrm{Jul}-2 \\
\text { Aug }\end{array}$ & $\begin{array}{l}\text { 9-11 Jul } \\
29 \text { Jul- } \\
2 \text { Aug }\end{array}$ & $\begin{array}{l}28 \text { Jul- } \\
2 \text { Aug }\end{array}$ \\
\hline 2003 & 1-3 Aug & & 12-14 Aug & & & & \\
\hline 2004 & 8-10 Aug & & 17-19 Aug & & & & \\
\hline 2005 & & 28-30 Jul & & $28-30 \mathrm{Jul}$ & & & $\begin{array}{c}28-30 \\
\text { May } \\
\text { 28-30 Jul }\end{array}$ \\
\hline 2006 & \begin{tabular}{|c|} 
5-7 Jul \\
10-13 Jul \\
20-28 Jul \\
\end{tabular} & $\begin{array}{l}10-13 \text { Jul } \\
20-24 \text { Jul } \\
26-29 \text { Jul }\end{array}$ & $\begin{array}{l}10-13 \mathrm{Jul} \\
16-28 \mathrm{Jul}\end{array}$ & 7-13 Jul & 6-11 Jul & & $\begin{array}{c}5-13 \mathrm{Jul} \\
23-27 \mathrm{Jul}\end{array}$ \\
\hline 2007 & 14-17 Jul & 15-17 Jul & 14-17 Jul & 15-17 Jul & & 15-17 Jul & 16-18 Jul \\
\hline 2008 & $\begin{array}{c}1-4 \text { Jul } \\
25-29 \text { Jul }\end{array}$ & & 25-29 Jul & & & & \\
\hline 2010 & $\begin{array}{c}\text { 2-4 Jul } \\
9-14 \mathrm{Jul}\end{array}$ & & & & & & \\
\hline
\end{tabular}

at Stubice station (13 hot spells). In 2003, 2004 and 2008, heat waves occurred only in Stubice and Legnica, which indicates the impact of the inflow of hot air masses from Western Europe. In 2002 (29 Jul - 2 Aug), 2006 (10-13 Jul) and 2007 (15-17 Jul) heat waves were widespread and the maximum temperatures were detected for three consecutive days over the same period at almost all stations. 


\subsection{Ozone pollution}

The European Directive on Ambient Air Quality and Cleaner Air for Europe (EC/2008/50) defines the thresholds for ozone exposure with respect to human health based on the maximum daily 8 -hour running mean of ozone concentrations. The Long Term Objective (LTO) is defined as the number of days when the maximum 8-hour running mean of ozone concentration exceeded $120 \mu \mathrm{g} / \mathrm{m}^{3}$. The Target Value (TV) is exceeded when the LTO is exceeded more than 25 times per calendar year at a particular station.

The number of days with exceedances of LTO was calculated for each station for each analysed year. Most LTO exceedances during the whole analysed period were at Czerniawa (461). Also, a high number of days with high ozone concentrations was recorded in Belsk (331 days) and Jarczew (256 days). At most stations, the number of days with TV exceedances occurred in 2002, 2003 and 2006 (60, 70, and 76, respectively). Also, the number of LTO exceedances was highest in these years (213, 218 and 207). Exceedances of TV were not observed in Leba, where the highest number of days with 8 -hour ozone concentration exceeding $120 \mu \mathrm{g} / \mathrm{m}^{3}$ was 20 in 2006.

The average number of days with LTO exceedances calculated for Widuchowa, Kuznia and Urad stations would have been probably higher if these stations had operated over the entire 15 -year period. The inclusion of stations with shorter time record can be justified by the fact that there were very few rural background air quality monitoring stations available for the analysed period in Poland.

Figure 6 presents the number of days with LTO exceedances. In 1997 and 2004 the number of days was significantly lower than in other years (8-9 days on average). In 1997, 1998, 2004 and 2010 exceedances of TV were not observed. From 2007 to 2011 the average number of LTO exceedances was quasi-constant.

To be coherent with the number of days with exceedances of LTO we calculated the sum of maximum 8-hour ozone levels over $120 \mu \mathrm{g} / \mathrm{m}^{3}$ as a measure of accumulated exposure to high concentrations (AOT60). The AOT60 (Accumulated Ozone Exposure above a Threshold of $60 \mathrm{ppb}$ ) was proposed in the draft version of the first ozone directive as an indicator of human exposure. Although AOT60 was not incorporated into the European Ambient Air Quality Directive, it is valuable for presented analysis as it accounts for the size and duration of the exceedances.

The accumulated exposure to ozone concentrations above the LTO threshold was calculated for each station and each year. This index was the highest in 2000, 2002, 2003 and 2006.

In 2000 and 2002 the exposure was comparable and relatively high at all stations. The index value was on average $322.39 \mu \mathrm{g} / \mathrm{m}^{3} \cdot$ day in 2000 and 


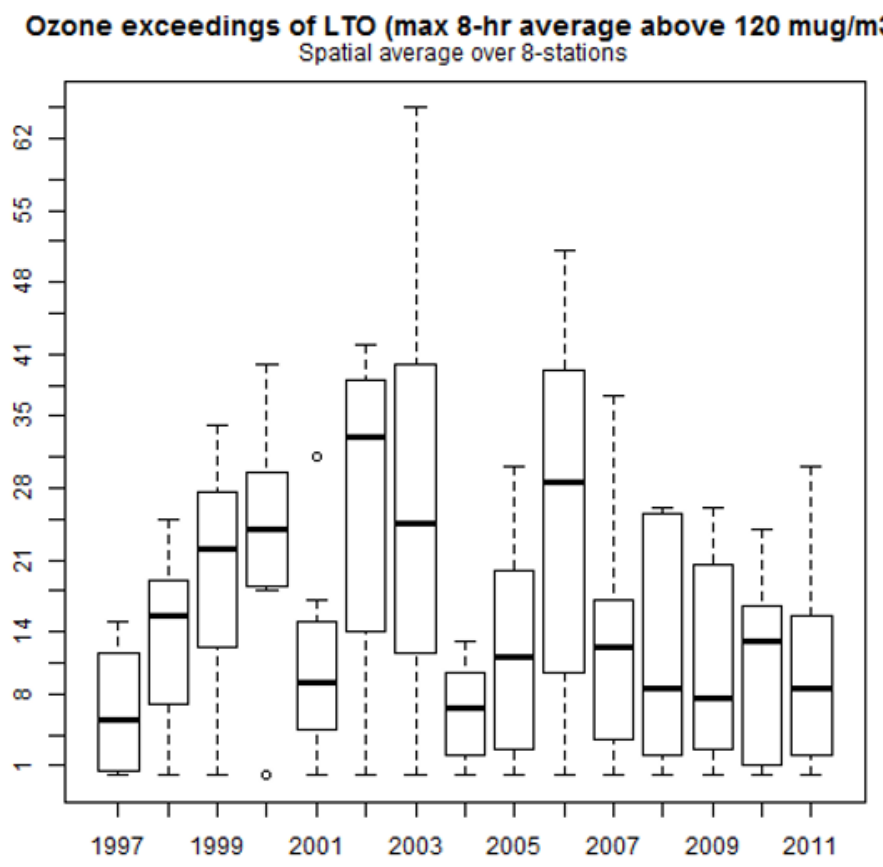

Fig. 6. Number of days with exceedances of $120 \mu \mathrm{g} / \mathrm{m}^{3}$ in respect to the maximum 8-hour running mean of ozone concentrations for 1997-2011.

$301.87 \mu \mathrm{g} / \mathrm{m}^{3} \cdot$ day in 2002. In 2003, stations located in the west and south of Poland showed higher exposure (Czerniawa - $1040.45 \mu \mathrm{g} / \mathrm{m}^{3}$ •day, Urad $487.22 \mu \mathrm{g} / \mathrm{m}^{3}$ day). Also, high index value was calculated for Belsk -570 $\mu \mathrm{g} / \mathrm{m}^{3}$ •day. Exceptionally high values were found in 2006 at stations located in different parts of Poland (Widuchowa $-703.55 \mu \mathrm{g} / \mathrm{m}^{3}$ day, Belsk -635.84 $\mu \mathrm{g} / \mathrm{m}^{3} \cdot$ day, Jarczew $-564.75 \mu \mathrm{g} / \mathrm{m}^{3} \cdot$ day).

In general, the highest exposure was seen at the mountain station Czerniawa, located at $645 \mathrm{~m}$ asl. This effect is partly caused by the elevated ozone concentration due to the transport from upper troposphere in the mountain regions. However, high ozone concentrations in the boundary layer resulting from photochemical production also contribute to the exposure observed in Czerniawa. Ozone exposure is often high at Belsk station (264.48 $\mu \mathrm{g} / \mathrm{m}^{3} \cdot$ day on average), which may indicate a favourable ozone production regime and the structure and pattern of precursors emission in the source impact region of the station.

Figure 7 presents the accumulated exposure to ozone concentrations higher than $120 \mu \mathrm{g} / \mathrm{m}^{3}$ for the maximum 8-hour running average. Highest mean exposure was observed in 2000, 2002, 2003 and 2006, although in 


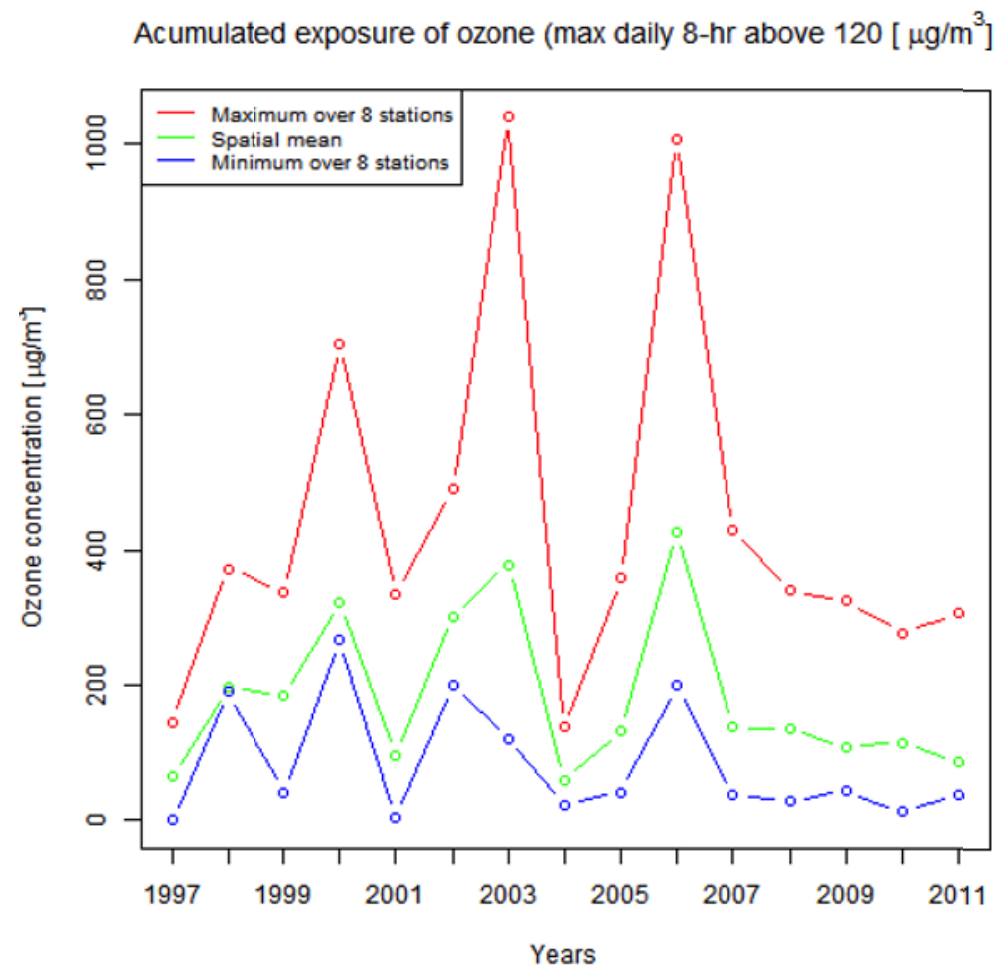

Fig. 7. Average accumulated exposure to ozone concentrations during days with LTO exceedances in 1997-2011 (green line - spatial average over eight air quality stations; blue line - minimum, red line - maximum).

2003 and 2006 the exposure in terms of average and maximum values was the highest. In 2000 and 2002 exposure variability was very small and high exposure was noted at all analysed stations. No trend was observed; however, till 2007 the variability seemed to increase while from 2007 to 2011 the exposure to high ozone concentrations at analysed stations was relatively constant.

Exceedances of the information threshold defined as 1-hour ozone concentrations higher than $180 \mu \mathrm{g} / \mathrm{m}^{3}$ were also analysed (Table 3). In 1997, 1999, 2001, 2004, 2007, 2008, 2009 and 2011 such high concentrations were not recorded at analysed stations. In 2002, 2005 and 2010 ozone concentrations exceeded the information threshold at only one station each year (Kuznia, Czerniawa and Widuchowa, respectively). Most exceedances of the information threshold were noted in 2000, 2003 and 2006 (19, 21 and 28, respectively). 
Table 3

Number of exceedances of the $180 \mu \mathrm{g} / \mathrm{m}^{3}$

in respect to 1-hour ozone concentrations in 1997-2011

\begin{tabular}{|c|c|c|}
\hline & Number of cases & Stations \\
\hline 1998 & 7 & $\begin{array}{c}\text { Łeba, Czerniawa, } \\
\text { Kuznia }\end{array}$ \\
\hline 2000 & 19 & $\begin{array}{c}\text { Łeba, Czerniawa, } \\
\text { Belsk }\end{array}$ \\
\hline 2002 & 2 & Kuznia \\
\hline 2003 & 21 & $\begin{array}{l}\text { Urad, Łeba, Czer- } \\
\text { niawa, Belsk, Ku- } \\
\text { znia }\end{array}$ \\
\hline 2005 & 1 & Czerniawa \\
\hline 2006 & 28 & $\begin{array}{c}\text { Jarczew, Belsk, } \\
\text { Czerniawa, } \\
\text { Widuchowa }\end{array}$ \\
\hline 2010 & 1 & Widuchowa \\
\hline
\end{tabular}

In most cases, high concentrations were observed at Czerniawa station. Information threshold at Belsk, Łeba and Kuźnia was exceeded three times during the analysed period.

\section{DISCUSSION}

An attempt was made to explore the relationship between the length and intensity of hot temperature spells and the intensity of excessive ozone concentrations.

In the first approach, the number of hot days at a given synoptic station in each year was paired with the number of LTO exceedances at the corresponding air quality monitoring station (Fig. 8). The temporal agreement between hot spells and episodes of high ozone concentration was not taken into account.

In general, most of the station pairs show dependence between the number of hot days and the number of days with ozone concentrations exceeding $120 \mu \mathrm{g} / \mathrm{m}^{3}$ in respect to the maximum 8-hour running average. A higher number of hot days corresponds to the increase of days with LTO exceedances at Warsaw-Belsk, Legnica-Czerniawa, Lublin-Jarczew, Słubice- 

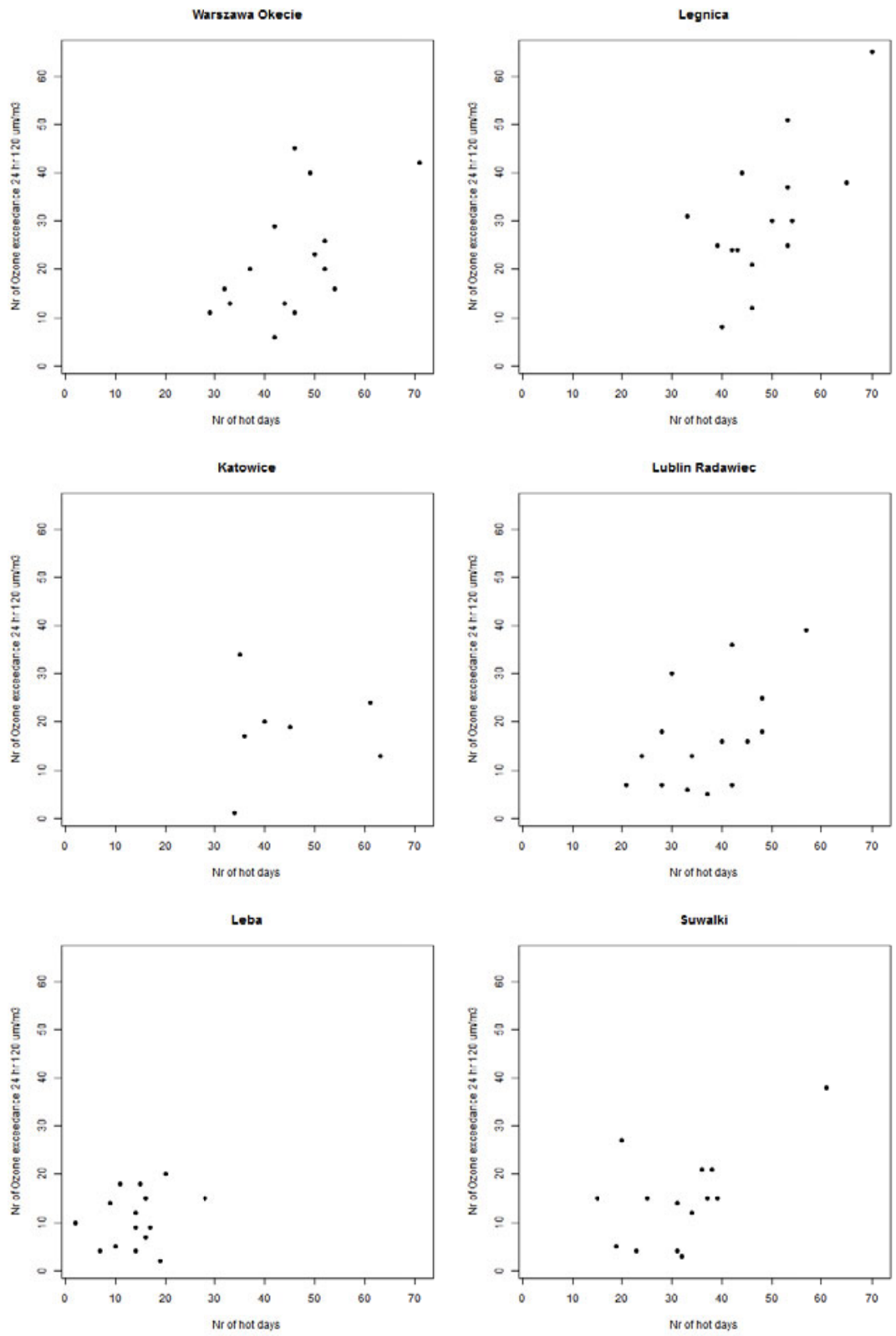

Fig. 8. Continued on next page. 

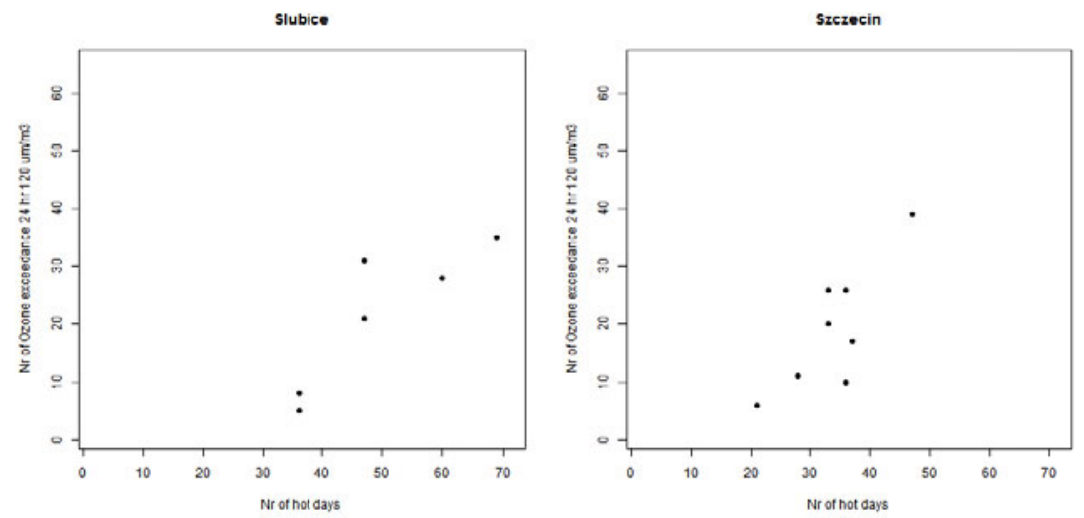

Fig. 8. Number of hot days at synoptic stations paired with number of LTO exceedances at the nearest rural background air quality station.

Urad and Szczecin-Widuchowa. The lowest number of hot days and LTO exceedances was observed at Łeba and Suwałki-Puszcza Borecka stations. Hence, the relation between the total number of hot days and LTO days was less evident at these particular stations. However, at Suwalki-Puszcza Borecka highest number of LTO days (38) observed in 2002 corresponded with exceptionally high number of hot days (61), which is not typical for this region.

In the next approach, the temporal agreement of hot days and ozone concentrations was taken into account. The average 8-hour ozone concentration during hot days for each pair of stations in each year was calculated (Fig. 9). The increase of ozone concentrations in relation to temperature during hot days was observed for most of the stations (Warszawa-Belsk, LegnicaCzerniawa, Lublin-Jarczew, Suwalki-Puszcza-Borecka and SzczecinWiduchowa. For Katowice-Kuźnia and Słubice-Urad the dependence is not clear due small range of the temperature variability during hot days (below $\left.1^{\circ} \mathrm{C}\right)$. Also, ozone concentration time series was shorter at these stations. The average 8-hour ozone concentrations during hot days in most cases were below the $120 \mu \mathrm{g} / \mathrm{m}^{3}$ threshold.

In the last approach, we analysed the maximum temperature for days with LTO exceedances. The average 8-hour average of ozone concentrations was calculated at each station and each year, as was the average maximum air temperature at the corresponding synoptic station (Fig. 10). For some stations during LTO days, an increase of the average ozone concentrations was found when the higher maximum temperature was observed (i.e., Warsaw- 
Belsk, Lublin-Jarczew, Szczecin-Widuchowa). For most of the stations the elevated ozone concentrations $\left(125-135 \mu \mathrm{g} / \mathrm{m}^{3}\right)$ were observed for air tem-
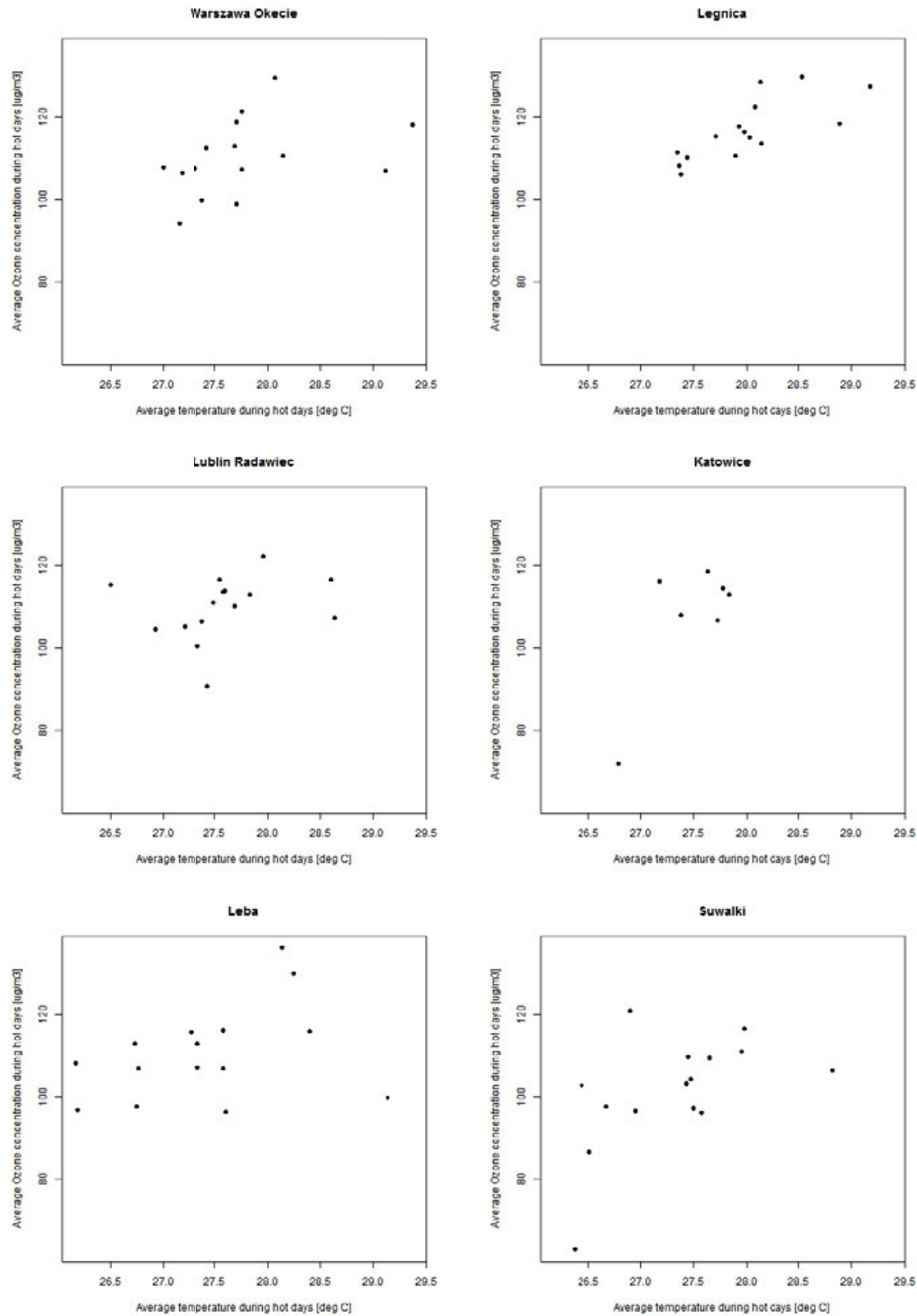

Fig. 9. Continued on next page. 

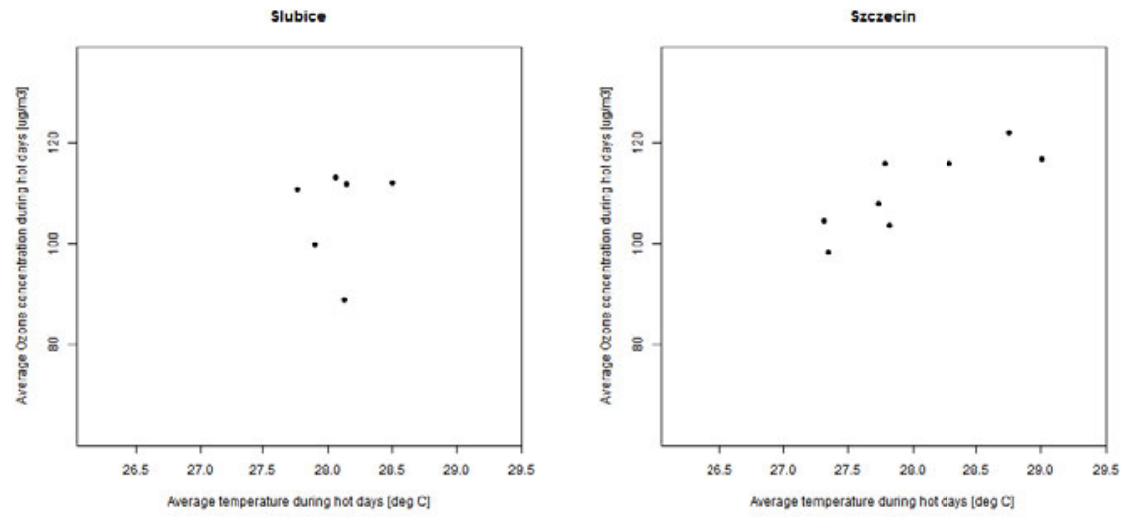

Fig. 9. Maximum temperature at synoptic stations paired with the average 8-hour ozone concentration at nearest rural background air quality station during hot days.

peratures higher than $24^{\circ} \mathrm{C}$. Łeba and Suwalki-Puszcza Borecka sta-tions were an exception, where relatively high concentrations occurred during days with average maximum temperature below $24^{\circ} \mathrm{C}$.

To assess spatial variability of ozone exposure in the context of thermal conditions, the following annual average diagnostics were calculated (Fig.11):

a number of days above the threshold $\left(25^{\circ} \mathrm{C}, 30^{\circ} \mathrm{C}\right.$ and $120 \mu \mathrm{g} / \mathrm{m}^{3}$, respectively)

$\square$ average value of the parameter during the days above the threshold

$\square$ accumulated value of the parameter during the days above the threshold.

In the case of the number of characteristic days, the spatial pattern is similar for all analysed parameters. Higher numbers of hot and very hot days were measured at stations in the south-western part of Poland (Słubice, Legnica, Katowice) as well as at Warsaw-Okecie station. The smallest number of days with high temperature was recorded at Łeba nad Suwałki. The observed pattern corresponds well to the numbers of days with LTO exceedances, which were the highest at Urad (Stubice), Czerniawa (Legnica), and Belsk (Warsaw-Okecie), and lowest in Leba (Łeba) and Puszcza Borecka (Suwałki).

In the case of the average value of the temperature during characteristic days, the differences between stations are very small (less than $1^{\circ} \mathrm{C}$ ). The temperature distribution pattern has a weak spatial correlation with the average ozone concentrations during days with LTO exceedances. At most 

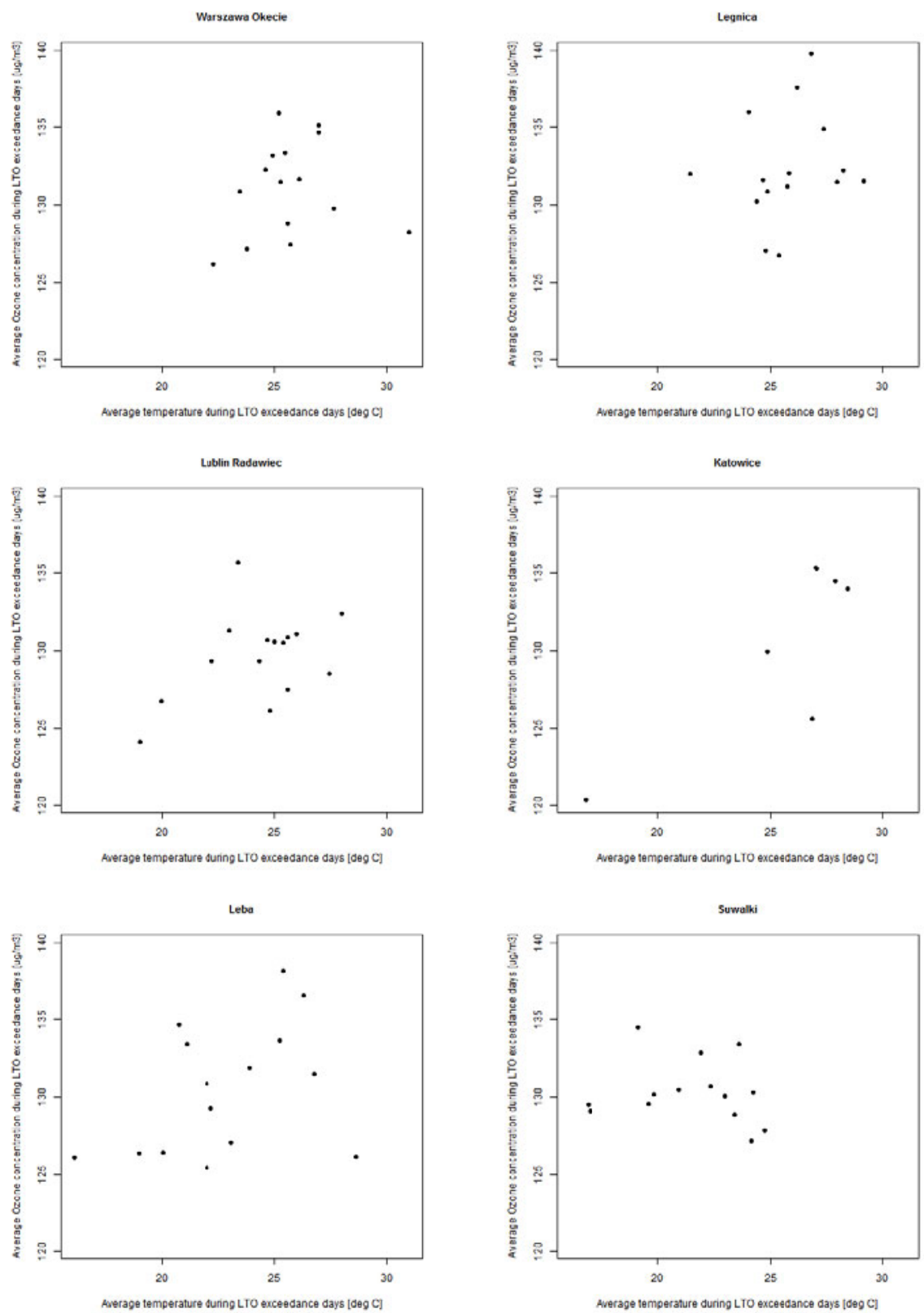

Fig. 10. Continued on next page. 

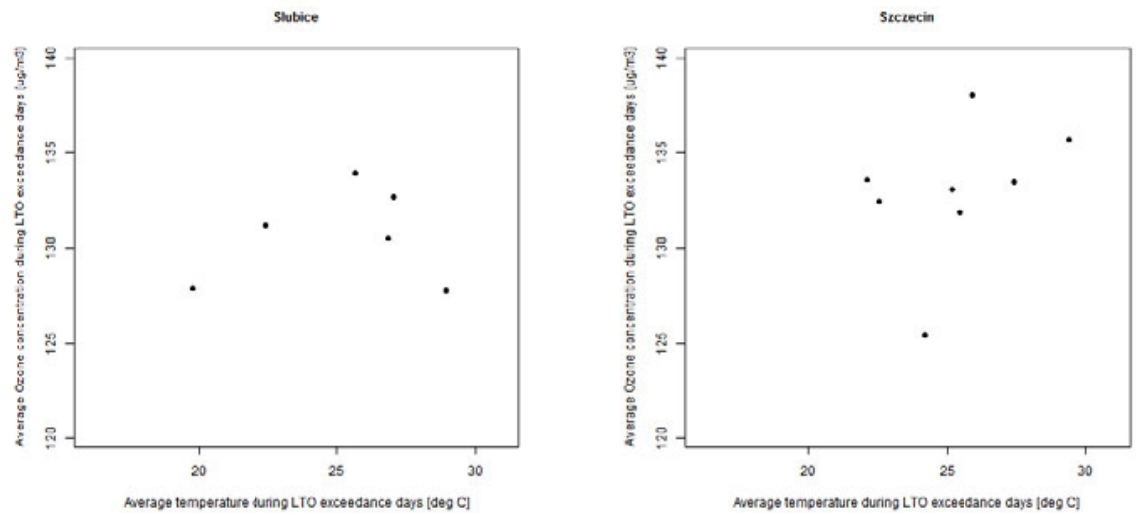

Fig. 10. Maximum temperature at synoptic stations paired with the average 8-hour ozone concentration at nearest rural background air quality station during days with LTO exceedances.

stations the average ozone concentration during the LTO days is $131 \mu \mathrm{g} / \mathrm{m}^{3}$, higher concentrations were observed at Czerniawa, which is a mountain station, and Widuchowa station located on the western border. As for the accumulated exposure to high temperature and ozone, the lowest values were recorded at stations located in the northern Poland (Łeba, Puszcza Borecka). The highest accumulated exposure was calculated for stations located along the south-western border. Spatial agreement for highest exposure is not obvious. Stations located in the central-eastern part of Poland show significant differences in the AOT60 values, which correspond well with differences in the accumulated temperature exposure.

Additional analysis was undertaken for exceedances of the information threshold $\left(180 \mu \mathrm{g} / \mathrm{m}^{3}\right)$ in respect to 1-hour ozone concentrations. Such cases occurred at least once at seven stations. During 15-year period, such high ozone concentrations were not observed only at Puszcza Borecka station. In general, the number of very hot days was not related to the number of exceedances of the ozone concentration threshold of $180 \mu \mathrm{g} / \mathrm{m}^{3}$. Also, the number of measurement points is too small to conclude.

For each case of the exceeding of the information threshold at air quality monitoring station, the maximum daily temperature from the corresponding synoptic station was assigned (Fig. 12). A similar number of the information threshold exceedances was found during days with the maximum temperature below $30^{\circ} \mathrm{C}$ ( 14 cases) and above $30^{\circ} \mathrm{C}$ ( 15 cases). However, during very hot days the ozone exposure was higher. An exception in the case recorded at Jarczew station in May 2006, which was connected with the advective episode with the inflow from the eastern direction (Gawuc et al. 2013). 


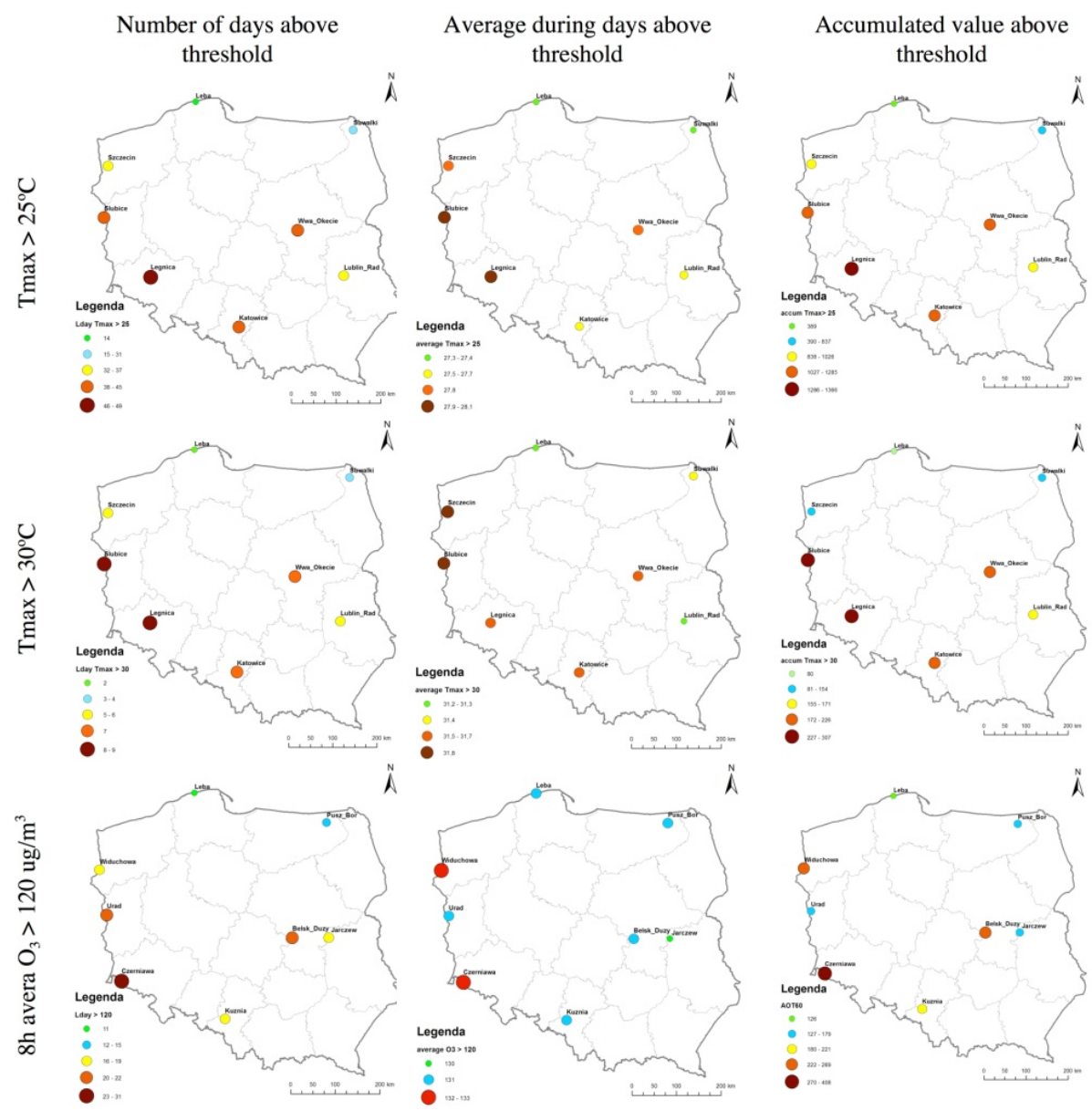

Fig. 11. Spatial distribution of number of days above the threshold, average value during the days above the threshold and accumulated value above the threshold for maximum daily temperature above $25^{\circ} \mathrm{C}$ and $30^{\circ} \mathrm{C}$ and ozone concentrations exceeding LTO.

The temporal agreement between heat wave periods (Table 2) and exceedances of the information threshold was assessed. The highest daily maximum concentrations were observed in 2000 and 2006. In 1998, 2002 and 2005 there was no coincidence between extreme temperature and ozone concentration maxima. In 2003 and 2006 there was one case per year when the exceedance of the information threshold took place during the heat wave. 
1-hr 03 concentration exceeding 180 treshold related to maximum temperature

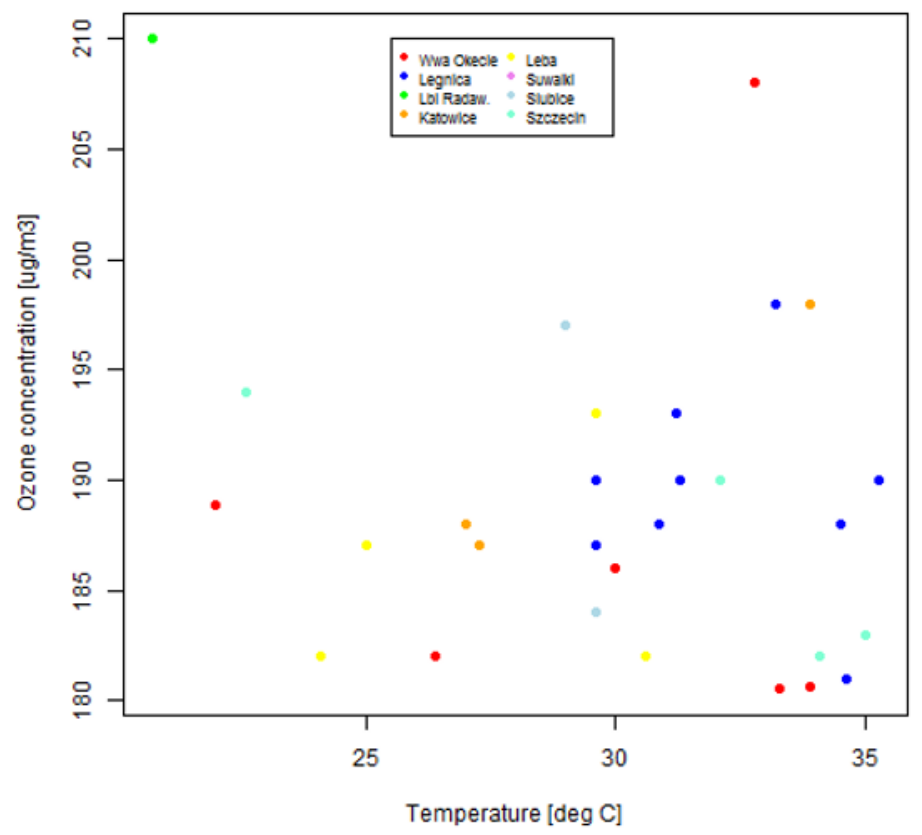

Fig. 12. Maximum temperature at synoptic stations paired with the daily maximum ozone concentration at nearest rural background air quality station exceeding information threshold.

\section{CONCLUSIONS}

The number of days with the maximum temperature exceeding $25^{\circ} \mathrm{C}$ ("hot days") and the number of days with maximum temperature exceeding $30^{\circ} \mathrm{C}$ ("very hot days") were calculated for a 15-year period (1997-2011). In addition, the average maximum temperature during these days was calculated. To assess ozone exposure, the number of days with exceedances of the LTO was calculated for each station for each analysed year. Also, an ozone exposure index (AOT60) was calculated, as a measure of the accumulated exposure to concentrations higher than $120 \mu \mathrm{g} / \mathrm{m}^{3}$ in terms of an 8-hour running average. Exceedances of the information threshold (1-hour concentrations higher than $180 \mu \mathrm{g} / \mathrm{m}^{3}$ ) were also taken into account.

Although it is believed that high air temperature results in an enhanced ozone formation, the outcome from the presented analysis of the relationship between hot weather periods and enhanced ozone pollution in Poland is not clear. 
High exposure to ozone concentrations in terms of values higher than $120 \mu \mathrm{g} / \mathrm{m}^{3}$ is correlated with the number of hot days (in 2002, 2003 and 2006). However, occurrence of very hot days, if not associated with longer hot weather periods, did not result in enhanced ozone pollution (i.e., in 1998, 2010). Highest 1-hour ozone concentrations were observed in 2000, 2003 and 2006. In general, episodes of very high ozone concentrations exceeding the $180 \mu \mathrm{g} / \mathrm{m}^{3}$ were not associated with heat wave periods at analysed locations. In 2000, such events were not associated with hot weather period during the summer. In contrast, in 2002, the information threshold was not exceeded although the number of days with the LTO exceedances and the number of hot and very hot days was high.

A relationship between the number of hot days and the number of days with the LTO exceedances was found for the set of all analysed stations. However, the analysis of the maximum 8-hour running average of ozone concentrations, calculated as a mean over the hot days, showed that during hot weather periods the LTO was not exceeded in most cases. Also, the average maximum temperature during and the 8-hour running average of ozone concentrations during the days with LTO exceedances does not show a quasi-linear relationship. In most cases the elevated ozone concentrations occurred during days when the maximum temperature was higher than $24^{\circ} \mathrm{C}$. Although a similar number of the information threshold exceedances was found during days with the maximum temperature below and above $30^{\circ} \mathrm{C}$, the ozone concentrations reached very high levels during very hot days.

The spatial variability of ozone exposure in the context of thermal conditions was found for the number of characteristic days. Average temperature during hot and very hot days weakly corresponds with the average ozone concentrations during days with LTO exceedances. The highest accumulated exposure on ozone concentrations was not determined by accumulated temperature exposure; however, for stations with lowest temperature exposure AOT60 was also low.

In general, warm summer periods with prolonged hot spells favours ozone formation at rural background stations. However, the temporal agreement between hot days or heat waves and periods with exceptionally high ozone concentration is not clear during the analysed 15-year period. Further analysis of the circulation types over Central Europe during ozone episodes will be undertaken.

Acknowledgements. This study was sponsored by the Polish National Centre of Science grant UMO-2011/01/B/STY10/04739 (Air quality in future climate in Central Europe). 


\section{References}

Bloomer, B.J., J.W. Stehr, C.A. Piety, R.J. Salawitch, and R.R. Dickerson (2009), Observed relationships of ozone air pollution with temperature and emissions, Geophys. Res. Lett. 36, 9, L09803, DOI: 10.1029/2009GL037308.

Camalier, L., W. Cox, and P. Dolwick (2007), The effects of meteorology on ozone in urban areas and their use in assessing ozone trends, Atmos. Environ. 41, 33, 7127-7137, DOI: 10.1016/j.atmosenv.2007.04.061.

Cardellino, C.A., and W.L. Chameides (1990), Natural hydrocarbons, urbanization and urban ozone, J. Geophys. Res. 95, D9, 13971-13979, DOI: 10.1029/ JD095iD09p13971.

Clark, T.L., and T.T. Karl (1982), Application of prognostic meteorological variables to forecasts of daily maximum one hour ozone concentrations in the northeastern United States, J. Appl. Meteorol. 21, 11, 1662-1671, DOI: 10.1175/1520-0450(1982)021<1662:AOPMVT>2.0.CO;2.

Della-Marta, P.M., J. Luterbacher, H. von Weissenfluh, E. Xoplaki, M. Brunet, and H. Wanner (2007), Summer heat waves over western Europe 1880-2003, their relationship to large-scale forcings and predictability, Clim. Dynam. 29, 2-3, 251-275, DOI: 10.1007/s00382-007-0233-1.

Fiala, J., L. Cernikovsky, F. de Leeuw, and P. Kurfuerst (2003), Air pollution by ozone in Europe in summer 2003. Overview of exceedances of EC ozone threshold values during the summer season April-August 2003 and comparisons with previous years, Copenhagen, European Environment Agency. EEA Topic Report 3/2003.

Gawuć, L., M. Jefimow, and J. Strużewska (2013), Impact of aerosol transport from biomass burning on surface ozone episode in Central Europe on 5 of May 2006. In: I National Conference on „Role of aerosols in the climate system", 25-27 September 2013, Warsaw, Poland.

Graczyk, D., and Z.W. Kundzewicz (2014), Changes in thermal extremes in Poland, Acta Geophys. 62, 6, 1435-1449, DOI: 10.2478/s11600-014-0240-7.

Guenther, A.B., P.R. Zimmerman, P.C. Harley, R.K. Monson, and R. Fall (1993), Isoprene and monoterpene emission rate variability - model evaluations and sensitivity analyses, J. Geophys. Res. 98, D7, 12609-12617, DOI: 10.1029/93JD00527.

Hodnebrog, Ø., S. Solberg, F. Stordal, T.M. Svendby, D. Simpson, M. Gauss, A. Hilboll, G.G. Pfister, S. Turquety, A. Richter, J.P. Burrows, and H.A.C. Denier van der Gon (2012), Impact of forest fires, biogenic emissions and high temperatures on the elevated Eastern Mediterranean ozone levels during the hot summer of 2007, Atmos. Chem. Phys. 12, 8727-8750, DOI: 10.5194/acp-12-8727-2012.

Im, U., R. Bianconi, E. Solazzo, I. Kioutsioukis, A. Badia, A. Balzarini, R. Baró, R. Bellasio, D. Brunner, C. Chemel, G. Curci, J. Flemming, R. Forkel, L. Giordano, P. Jiménez-Guerrero, M. Hirtl, A. Hodzic, L. Honzak, 
O. Jorba, C. Knote, C. Kuenen, J.P. Jeroen P.A. Makar, A. Manders-Groot, L. Neal, J.L. Pérez, G. Pirovano, G. Pouliot, R. San Jose, N. Savage, W. Schroder, R.S. Sokhi, D. Syrakov, A. Torian, P. Tuccella, J. Werhahn, R. Wolke, K. Yahya, R. Zabkar, Y. Zhang, J. Zhang, C. Hogrefe, and S. Galmarini (2015), Evaluation of operational on-line-coupled regional air quality models over Europe and North America in the context of AQMEII phase 1: Part I: Ozone, Atmos. Environ. 115, 404-420, DOI: 10.1016/ j.atmosenv.2014.09.042.

Im, U., K. Markakis, A. Poupkou, D. Melas, A. Unal, E. Gerasopoulos, N. Daskalakis, T. Kindap, and M. Kanakidou (2011), The impact of temperature changes on summer time ozone and its precursors in the Eastern Mediterranean, Atmos. Chem. Phys. 11, 8, 3847-3864, DOI: 10.5194/acp-11-38472011.

Jacob, D.J., J.A. Logan, G.M. Gardner, R.M. Yevich, C.M. Spivakovsky, S.C. Wofsy, S. Sillman, and M.J. Prather (1993), Factors regulating ozone over the United States and its export to the global atmosphere, J. Geophys. Res. 98, D8, 14817-14826, DOI: 10.1029/98JD01224.

Korsog, P.E., and G.T. Wolff (1991), An examination of urban ozone trends in the northeastern US (1973-1983) using a robust statistical method, Atmos. Environ. B. 25, 1, 47-57, DOI: 10.1016/0957-1272(91)90039-H.

Kyselý, J. (2010), Recent severe heat waves in central Europe: how to view them in a long-term prospect? Int. J. Climatol. 30, 1, 89-109, DOI: 10.1002/joc. 1874.

Mahmud, A., M. Tyree, D. Cayan, N. Motallebi, and M.J. Kleeman (2008), Statistical downscaling of climate change impacts on ozone concentrationsin California, J. Geophys. Res. 113, D21, D21103, DOI: 10.1029/2007JD009534.

Meehl, G.A., and C. Tebaldi (2004), More intense, more frequent, and longer lasting heatwaves in the 21 st century, Science 305, 5686, 994-997, DOI: 10.1126 / science. 1098704.

Melkonyan, A., and P. Wagner (2013), Ozone and its projection in regard to climate change, Atmos. Environ. 67, 287-295, DOI: 10.1016/j.atmosenv. 2012.10.023.

Papanastasiou, D.K., D. Melas, and H.D. Kambezidis (2014), Heat waves characteristics and their relation to air quality in Athens, Glob. NEST J. 16, 5, 919928.

Pehnec, G., L. Klasinc, G. Šorgo, and V. Vađića (2009), Analysis of summer 2006 ozone pollution in Zagreb, Croat. Chem. Acta 82, 1, 329-335.

Pellegrini, E., G. Lorenzini, and C. Nali (2007), The 2003 European Heat Wave: Which Role for Ozone? Some Data from Tuscany, Central Italy, Water Air Soil Poll. 181, 1, 401-408, DOI: 10.1007/s11270-006-9310-z.

Rasmussen, D.J., A.M. Fiore, V. Naik, L.W. Horowitz, S.J. McGinnis, and M.G. Schultz (2012), Surface ozone-temperature relationships in the east- 
ern US: A monthly climatology for evaluating chemistry-climate models, Atmos. Environ. 47, 142-153, DOI: 10.1016/j.atmosenv.2011.11.021.

Ryan, W.F., B.G. Doddridge, R.R Dickerson, R.M. Morales, K.A. Hallock, P.T. Roberts, D.L. Blumenthal, J.A. Anderson, and K.L. Civerolo (1998), Pollutant transport during a regional $\mathrm{O} 3$ episode in the mid-Atlantic states, J. Air Waste Manage. Assoc. 48, 9, 786-797, DOI: 10.1080/10473289.1998. 10463737.

Sillman, S. (1999), The relation between ozone, NOx and hydrocarbons in urban and polluted rural environments, Atmos. Environ. 33, 12, 1821-1845, DOI: 10.1016/S1352-2310(98)00345-8.

Sillman, S., and P.J. Samson (1995), Impact of temperature on oxidant photochemistry in urban, polluted rural and remote environments, J. Geophys. Res. 100, D6, 11497-11508, DOI: 10.1029/94JD02146.

Solazzo, E., R. Bianconi, R. Vautard, K.W. Appel, M.D. Moran, and C. Hogrefe et al. (2012), Model evaluation and ensemble modeling of surface-level ozone in Europe and North America in the context of the AQMEII; Atmos. Environ. 53, 60-74, DOI: 10.1016/j.atmosenv.2012.01.003.

Solberg, S., Ø. Hov, A. Søvde, I.S.A. Isaksen, P. Coddeville, H. De Backer, C. Forster, Y. Orsolini, and K. Uhse (2008), European surface ozone in the extreme summer 2003, J. Geophys. Res. 113, D7, D07307, DOI: 10.1029/ 2007JD009098.

Stathopoulou, E., G. Mihalakakou, M. Santamouris, and H.S. Bagiorgas (2008), On the impact of temperature on tropospheric ozone concentration levels in urban environments, J. Earth Syst. Sci. 117, 3, 227-236, DOI: 10.1007/ s12040-008-0027-9.

Steiner, A.L., A.J. Davis, S. Sillman, C. Robert, R.C. Owen, A.M. Michalak, and A.M. Fiore (2010), Observed suppression of ozone formation at extremely high temperatures due to chemical and biophysical feedbacks, Proc. Nat. Acad. Sci. U.S.A. 107, 46, 19685-19690, DOI: 10.1073/pnas.1008336107.

Struzewska, J., and J.W. Kaminski (2008), Formation and transport of photooxidants over Europe during the July 2006 heat wave - observations and GEM-AQ model simulations, Atmos. Chem. Phys. 8, 721-736, DOI: 10.5194/acp-8721-2008.

Struzewska, J., J.W. Kaminski, M. Zdunek, and R. Cesari (2006), Impact of synoptic scale circulation patterns on pollutants' distribution over Central-Eastern Europe, ACCENT Report 8.06, Air Quality in Eastern Europe: Review of Measurement and Modelling Practices and Needs. C. Granier, P. Monks, O. Tarasova, S. Tuncel, P. Borrel (eds.), P\&PMB Consultants.

Tressol, M., C. Ordonez, R. Zbinden, J. Brioude, V. Thouret, C. Mari, P. Nedelec, J.-P. Cammas, H. Smit, H.-W. Patz, and A. Volz-Thomas (2008), Air pollution during the 2003 European heat wave as seen by MOZAIC airliners, Atmos. Chem. Phys. 8, 2133-2150, DOI: 10.5194/acp-8-2133-2008. 
Twardosz, R., and A. Batko (2012), Heat waves in Central Europe (1991-2006), Int. J. Global Warming 4, 3-4, 261-272, DOI: 10.1504/IJGW.2012.049430.

Twardosz, R., and U. Kossowska-Cezak (2015), Exceptionally hot and cold summers in Europe (1951-2010), Acta Geophys. 63, 1, 275-300, DOI: 10.2478/ s11600-014-0261-2.

Vautard, R., C. Honore, and M. Beekmann, and L. Rouil (2005), Simulation of ozone during the August 2003 heat wave and emission control scenarios, Atmos. Environ. 39, 16, 2957-2967, DOI: 10.1016/j.atmosenv.2005.01.039.

Vieno, M., A.J. Dore, D.S. Stevenson, R. Doherty, M.R. Heal, S. Reis, S. Hallsworth, L. Tarrason, P. Wind, D. Fowler, D. Simpson, and M.A. Sutton (2010), Modelling surface ozone during the 2003 heat-wave in the UK, Atmos. Chem. Phys. 10, 16, 7963-7978, DOI: 10.5194/acp-10-7963-2010.

Wesley, M.L. (1989), Parameterization of surface resistances to gaseous dry deposition in regional-scale numerical models, Atmos. Environ. 23, 6, 1293-1304.

Received 2 October 2015

Received in revised form 21 February 2016

Accepted 29 March 2016 